\title{
NOTE
}

\section{Comparison of selected strains of infectious hematopoietic necrosis virus (IHNV) using neutralizing trout antisera}

\author{
B. Basurco, S. Yun, R. P. Hedrick * \\ Department of Medicine, School of Veterinary Medicine, University of California, Davis, California 95616, USA
}

\begin{abstract}
Antisera against representative strains of infectious hematopoietic necrosis virus (IHNV) from each of the 5 electropherotypes were prepared in rainbow trout Oncorhynchus mykiss following injections with live virus. Serum cross-neutralization comparisons by $50 \%$ plaque neutralization tests (PNT) showed low antigenic heterogeneity between the viruses, as calculated by $1 / r$, a measure of the antigenic relationship between 2 virus types. The only virus strain clearly different from the others was the representative electropherotype 2 isolate (CST-82), with $1 / r$ values from 5.2 to 15.6 when compared to the other isolates. The $1 / r$ values obtained for the type 2 IHNV isolate were, however, not greater than 20, a value established as the criterion for distinguishing serotypes. The other IHNV isolates tested formed a homogeneous group sharing $1 / r$ values of 2.1 or less. These studies provide the first evidence that rainbow trout respond distinctly with respect to the production of serum neutralizing antibodies between certain strains of IHNV. A further characterization of these responses will be important to the interpretation of epidemiological studies and the development of vaccines for the control of IHNV.
\end{abstract}

The salmonid rhabdovirus infectious hematopoietic necrosis virus (IHNV) causes commercially significant losses in susceptible populations of both captive and wild fish (Wolf 1988). This agent is endemic among populations of salmon on the west coast of the USA and Canada but is also known from Europe, Japan, Taiwan, Korea, and the People's Republic of China (Sano et al. 1977, Chen et al. 1985, Bovo et al. 1987, Hattenberger-Baudouy 1988, Luqi \& Zhizhuang 1988 , J. Park, Ulsan University, Korea, pers. comm.). Although fry are the most susceptible stage to virusinduced mortality (Amend \& Nelson 1977), larger fish also suffer from both active infections and the sequelae of IHNV.

\footnotetext{
- Addressee for correspondence
}

Attempts to group or separate IHNV isolates have followed the virus since its initial identification. Three presumably different viral diseases were described among sockeye salmon Oncorhynchus nerka in Oregon (OSV), Sacramento River chinook salmon in California (SRCV), and rainbow trout Oncorhynchus mykiss and sockeye salmon in British Columbia (IHNV) (Wolf 1988). McCain et al. (1971) compared these 3 virus strains by neutralization using a polyclonal rabbit antiserum and found that OSV and IHNV were indistinguishable while SRCV was closely related to the other 2 viruses. Because of the inability to easily distinguish strains or serotypes of IHNV using polyclonal rabbit serum, alternative approaches were sought. Hsu et al. (1986) found that differences in the electrophoretic patterns of the $N$ and $G$ structural polypeptides using SDS PAGE could be used to separate IHNV strains into 5 groups or electropherotypes. The potential antigenic relationships of viruses in different electropherotypes were pursued by Engelking et al. (1991) who compared viruses from each of these 5 electropherotypes using 2 rabbit antisera prepared against types 1 and 4 whole virus and 2 antisera to the partially purified G protein of types 1 and 4 IHNV. Although their comparisons did not include full crossneutralizations for each of the 5 electropherotypes ( 5 sera $\times 5$ viruses), they concluded that the antigenic differences observed between virus strains were sufficient to define variants but not multiple serotypes. Additionally, they demonstrated that fish immunized with partially purified $G$ protein from type 1 virus were protected when challenged with type 2 or 5 virus. These comparisons and those of McCain et al. (1971) and others studying different phenotypic characters of the virus suggested that there are no great differences among strains of IHNV and that strains of the virus tend to be related more by geographic location than by host origin. 
The use of monoclonal antibodies (mabs), both neutralizing and binding, has helped to overcome in part the poor resolving powers of low titered rabbit antisera used in early comparisons (Winton 1991). Winton et al. (1988) and Ristow \& Arnzen (1991) have shown that at least 4 groups of viruses can be distinguished by panels of currently available mabs.

Although antibodies raised in rabbits and mice have been and will continue to be useful in examining important viral epitopes involved in virus neutralization, fish antibodies to IHNV are the ultimate indicators of the salmonid's response to viral infections. The use of this serological response for epidemiological studies and vaccine development therefore depends upon a better understanding of the fishes' capability to distinguish between strains of IHNV. The existence and significance of neutralizing antibodies in salmonids infected with IHNV were first demonstrated by Amend \& Smith (1974) and practical tests for the demonstration of antibodies were developed by HattenbergerBaudouy et al. (1989). Using this latter technique we have examined the relatedness of 6 IHNV isolates, representing each of the 5 electropherotypes, by their response in cross-neutralization tests to hyperimmune serum prepared in rainbow trout.

Materials and methods. Cell culture: All virus isolates were propagated in the EPC (epithelioma papulosum cyprini) cell line, derived from common carp Cyprinus carpio (Fijan et al. 1983). The cells were grown in minimal essential medium (MEM) containing Eagle's salts supplemented with $7.5 \%$ fetal bovine serum, $2 \mathrm{mM}$ L-glutamine, $50 \mathrm{IU} \mathrm{ml}^{-1}$ of penicillin and $50 \mu \mathrm{g} \mathrm{ml}^{-1}$ of streptomycin.

Virus isolates: Six isolates were used in this study (Table 1). They were selected to represent each of the 5 electropherotypes of IHNV as described by Hsu et al. (1986). A second type 3 virus isolate from coho salmon $O$. kisutch adults at the Trinity River Hatchery (CA, USA $_{i}$ LaPatra et al. 1989) was also included. The isolates were not plaque purified before use. To estimate concentrations needed for subsequent plaque neutralization tests (PNT), viruses were titrated by a method

Table 1. Representative isolates of infectious hematopoietic necrosis virus (IHNV) from the 5 electropherotypes used for comparison by cross-neutralization

\begin{tabular}{|c|c|c|c|c|}
\hline Jsolate & Host species & Location (USA) & Year & Type ${ }^{a}$ \\
\hline RB-76 & Steelhead $^{\mathrm{b}}$ & Deschutes River, OR & 1976 & 1 \\
\hline CST-82 & Rainbow trout & Clear Springs, ID & 1982 & 2 \\
\hline Trinity & Coho salmon & Trinity River, CA & 1985 & 3 \\
\hline $\mathrm{SRCV}$ & Chinook salmon & Sacramento River, CA & 1966 & 3 \\
\hline Coleman & Chinook salmon & Sacramento River, CA & 1983 & 4 \\
\hline Cedar & Sockeye salmon & Cedar River, WA & 1979 & 5 \\
\hline
\end{tabular}

similar to that described by Burke \& Mulcahy (1980). Modifications to that method included incubation of virus dilutions at $4^{\circ} \mathrm{C}$ for $16 \mathrm{~h}$ prior to a $1 \mathrm{~h}$ adsorption on EPC cells at $15^{\circ} \mathrm{C}$ after which a methylcellulose overlay was added.

Preparation of fish antisera: Antisera to the 6 IHNV strains were prepared in 2 yr old rainbow trout. At least 3 trout were injected for production of antisera against each virus isolate. These fish were obtained from the American River Hatchery, California Department of Fish and Game, Rancho Cordova, CA, and were maintained at the Fish Disease Laboratory at Univ. of California, Davis, in 6501 tanks receiving $15^{\circ} \mathrm{C}$ well water and fed a commercial pelleted ration daily. The American River Hatchery has no history of IHNV and testing of serum prior to injcction showed no evidence of anti-IHNV neutralizing activity. The fish were anesthetized with MS-222 (0.1 $\left.\mathrm{mg} \mathrm{l}^{-1}\right)$ prior to intraperitoneal injections with virus or collection of blood samples. Trout received 4 injections at $3 \mathrm{wk}$ intervals with $0.1 \mathrm{ml}$ of cell-free supernatant contain-

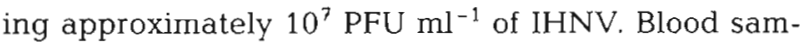
ples were drawn from the caudal vein at $10 \mathrm{~d}$ after the last injection. The antisera were heat inactivated for $30 \mathrm{~min}$ at $45^{\circ} \mathrm{C}$ prior to storage at $-70^{\circ} \mathrm{C}$.

$50 \%$ plaque neutralization test (50\% PNT): The PNT technique was performed as previously described by Olesen \& Jørgensen (1986) for viral hemorrhagic septicemia virus (VHSV) but the neutralization time was increased from 1 to $16 \mathrm{~h}$ (Hattenberger-Baudouy et al. 1989). All virus-antibody mixtures in 96-well culture plates were performed in the presence of normal trout serum diluted $1: 40$ as a source of complement. Both negative and positive serum controls were included in each test. Initial positive control sera were kindly provided by Dr P. de Kinkelin (INRA, Jouy-enJosas, France) but later were replaced by anti-RB-76 IHNV trout serum. Negative control sera were from virus-free trout. Eight 3-fold dilutions of trout sera were mixed with $120 \mu \mathrm{l}$ of virus (2000 PFU ml-1). After $30 \mathrm{~min}$ at $15^{\circ} \mathrm{C}$, a complement source (trout sera) was added and then the mixtures were incubated at $4^{\circ} \mathrm{C}$ for $16 \mathrm{~h}$. The mixtures were then placed onto EPC monolayers in 24-well culture plates, adsorbed for $1 \mathrm{~h}$ at $15^{\circ} \mathrm{C}$ prior to adding a methylcellulose overlay. The plates were incubated until clear virus plaques were observed in the negative controls (6 to $7 \mathrm{~d}$ ). The cells were then fixed and stained with $10 \%$ formalin and $1 \%$ crystal violet, the plaques counted, and the $50 \%$ PNT calculated as the reciprocal value of the highest serum dilution causing $50 \%$ reduction of the number of plaques found in the presence 
of normal trout serum. The antigenic relationships $(1 / r)$ between the IHNV isolates were calculated from the formula: $r=$ $r_{1} \times r_{2}$, where $r_{1}$ and $r_{2}$ are the titer ratios. The titer ratio is obtained by dividing the heterologous titer by the homologous titer for each respective antiserum (Archetti \& Horsfall 1950). The value $1 / r$ then gives the extent of the antigenic difference between 2 viruses when both viruses and their respective antisera are used in crossneutralization tests.

Results. Preliminary studies: Initial studies showed that virus plaques developed more readily and were more easily observed in 24-well rather than 96-well plates; therefore, the former were used for all neutralization assays. With nearly all sera a slight reduction (approximately $15 \%$ ) in plaque number was obtained in the first 2 serum dilutions $(1: 10$ and $1: 30$ ). These dilutions also frequently displayed cytotoxic activity. A $100 \%$ plaque reduction was seldomly achieved in the sera tested. A low number of plaques (from 1 to 5) normally escaped neutralization presumably due to antibody aggregation or the interference effect described by Mandel (1985).

The immunization protocol of adult trout with live IHNV was effective as demonstrated by serum neutralization titers up to 21870 . Pre-immune trout sera were found to be free of neutralizing antibodies against IHNV. A single bleeding was found to be satisfactory for collection of immune serum and less traumatic than repeated bleedings of individual fish.

The magnitude of the immune responses differed among immunized fish. Some trout produced high titers of neutralizing antibodies whereas others were comparatively unresponsive. By using 3 fish for each virus, at least 1 serum with a good PNT titer was obtained for each of the 5 virus strains. The lower titer of neutralizing antibodies against the Trinity isolate of IHNV (found in all 3 fish) may be related to a lack of multiplication of this virus in rainbow trout. Experimental infections in our laboratory have shown that the Trinity isolate has a low virulence for rainbow trout (S. Yun unpubl. data).

Cross-neutralizations: Trout sera with the highest PNT titer for each virus isolate were selected for the cross-neutralization tests with the 6 IHNV isolates. Serum was used from individual fish and never pooled even when it originated from trout injected with the same virus. Each of the IHNV isolates was neutralized by its homologous antiserum at the highest titer, except for the Coleman isolate, which showed greater neutralization by a heterologous anti-SRCV serum (Table 2). In our analysis the homologous PNT titers ranged from 810 for the Trinity isolate to 21870 for the $\mathrm{RB}-76$ isolate.

The calculated $1 / r$ values for all virus isolates are given in Table 3 . The 6 IHNV isolates could be placed in 2 groups based on their $1 / r$ values: one containing RB-76, Trinity, SRCV, Coleman and Cedar isolates $(1 / r=1.0$ to 2.1$)$, and the second containing just the CST-82 isolate, with $1 / r$ values that ranged from 5.2 to 15.6 .

Discussion. The antigenic relationship between different IHNV isolates was first studied by neutralization using polyclonal antisera (McCain et al. 1971). Later studies by Winton et al. (1988) and Ristow \& Arnzen (1991) with neutralizing monoclonal antibodies to the IHNV glycoprotein allowed the distinction between certain IHNV isolates. Studies using fish sera were initially plagued by poorly developed tests for the detection of neutralizing antibodies. HattenbergerBaudouy et al. (1989) showed, however, that with 
appropriate modifications the detection of fish neutralizing antibodies was a practical and useful test. Fish antibodies have not been used extensively for investigating serological relationships. Kelly \& Nielsen (1990) examined differences between strains of infectious pancreatic necrosis virus (IPNV) and VestergårdJørgensen et al. (1991) showed that sera from trout naturally infected with IHNV and VHSV contain antibodies that recognize shared as well as distinct epitopes on proteins from both viruses.

In our studies, cross-neutralization comparisons of 6 IHNV isolates representing the 5 electropherotypes separated them into 2 distinct groups. However, the $1 / r$ values marking the boundary between serotypes of $>20$ (Vestergård-Jørgensen 1972), as originally described for enteroviruses but later appiied to IPNV', were not observed. The consistent demonstrations of differences obtained between the CST-82 isolate and the other isolates, however, suggested some distinct antigenic characteristics. This distinction between type 2 and the other IHNV strains can be compared to the extreme homogeneity observed with the other viruses and their respective sera $(1 / r$ values $\leq 2.1)$. Our studies on the antigenic relationships of these few isolates of IHNV suggest that trout do not discriminate with high fidelity between most types of the virus. This applies to viruses from different host origins and geographical regions and belonging to groups based on different electrophoretic patterns (Hsu et al. 1986) or neutralizing reactions with mabs (Winton et al. 1988, Ristow \& Arnzen 1991).

The high level of cross-reactivity found between trout serum and IHNV strains suggests that the fish recognizes certain dominant antigens associated with neutralization on all the isolates we tested. In this regard our results agree with those of Engelking \& Leong (1989) and Engelking et al. (1991) who showed that a single type of $1 \mathrm{HNV}$ can induce a protective response to the 5 biochemical types of IHNV. Based on their cross-protection studies and some limited comparisons of rabbit antisera to whole virus and $G$ protein for types 1 and 4 IHNV, production of a vaccine based on a sole type of IHNV has the potential to protect against other known electropherotypes

Realizing the limitations of neutralization comparisons using only representative strains (rather than all possible isolates) of IHNV as presented here in our study, there appears to be evidence that trout can distinguish between certain strains of IHNV. Certainly warranted are additional neutralization comparisons including many more representatives of the 5 electropherotypes. Also, comparisons with representative strains from other typing schemes (e.g. those using mabs) are needed. These comparisons should further demonstrate how the trout recognizes different IHNV isolates with respect to antibodies important to virus neutralization and protection that might be afforded by vaccination. In addition, studies on the extent of the overlap in the antigenic determinants of type 2 IHNV by competition assays between type 1 and type 2 sera are planned. We presume these additional studies will support the suggestion that strains of IHNV originating in the Idaho region have developed certain characteristics that allow them to be distinguished from other IHNV strains by neutralization comparisons.

Although the trout in our study distinguished the type $2 \mathrm{IHNV}$ strain from the others, the extent of crossreaction with all types of IHNV tested was sufficient to allow the use of trout antibodies as diagnostic tools. Presumably these trout sera, as found with most rabbit anti-IHNV serd, will recognize any IHNV strain, a feature currently not available even with extensive panels of neutralizing mabs. This is supported by recent studies with the HO-7 isolate of IHNV, a strain not recognized by 7 commonly employed mabs (J. R. Winton, U.S. Fish and Wildlife Service, Seattle, WA, pers. comm.). We found that all 6 trout antisera used in our current study neutralized the HO- 7 strain (unpubl. data).

In conclusion, these preliminary investigations into the response of rainbow trout to representative IHNV strains provide the first evidence that trout recognize antigenic regions important to the development of neutralizing antibodies on viruses distinguished using electrophoresis or reactions with mabs. Their ability to distinguish between virus strains, however, appears to be limited. These initial studies suggest that trout can recognize certain viruses as distinct strains (e.g. type 2 IHNV used in our study). Additional comparisons with more IHNV strains from each of the electrophoretic groups are warranted to confirm this apparent pattern. Investigation of the relative importance of these neutralizing antibodies as measures of the protection present from challenge is also needed.

Acknowledgements. This work was supported in part by Western Region Aquaculture Consortium of the U.S. Department of Agriculture, Fish Restoration Act Funds administered by the California Department of Fish and Game and a fellowship provided to Dr B. Basurco by the Instituto Nacional de Investigaciones Agrarias, Spain.

\section{LITERATURE CITED}

Amend, D. F., Nelson, J. R. (1977). Variation in the susceptibility of sockeye salmon Oncorhynchus nerka to infectious hematopoietic necrosis virus. J. Fish Biol. 11: 567-573

Amend, D. F., Smith, L. (1974). Pathophysiology of infectious hematopoietic necrosis virus disease in rainbow trout (Salmo gairdneri): early changes in blood and aspects of the immune response after injection of IHN virus. J. Fish. Res. Bd Can. 31: 1371-1378 
Archetti, I., Horsfall, F. L. (1950). Persistent antigenic variation of influenza $A$ viruses after incomplete neutralization in vivo with heterologous immune serum. J. exp. Med. 92 : 441-462

Bovo, G., Giorgetti, G., Jørgensen, P. E. V., Olesen, N. J. (1987). Infectious hematopoietic necrosis: first detection in Italy. Bull. Eur. Ass. Fish Pathol. 7: 124

Burke, J. A., Mulcahy, D. (1980). Plaquing procedure for infectious hematopoietic necrosis virus. Appl. environ. Microbiol. 39: 872-876

Chen, S. N., Kou, G. H., Hedrick, R. P., Fryer, J. L. (1985). The occurrence of viral infections of fish in Taiwan. In: Ellis, A. E. (ed.) Fish and shellfish pathology. Academic Press, London, p. 313-319

Engelking, H. M., Harry, J. B., Leong, J. C. (1991). Comparison of representative strains of infectious hematopoietic necrosis virus by serological neutralization and cross-protection asssays. Appl, environ. Microbiol. 57: $1372-1378$

Engelking, H. M., Leong, J. C. (1989). Glycoprotein from infectious hematopoietic necrosis virus (IHNV) induces protective immunity against five IHNV types. J. aquat. Anim. Health 1: 291-300

Fijan, N., Salimanovic, D., Bearzotti, M., Muzinic, D., Zwillenberg, L. O., Chilmonczyk, S., Vautherot, J. F., de Kinkelin, P. (1983). Some properties of the Epithelioma Papulosum Cyprini (EPC) cell line from carp Cyprinus carpio. Ann. Virol. (Inst. Pasteur) 134E: 207-220

Hattenberger-Baudouy, A. M. (1988). La nécrose hématopoiétique infectieuse ( $\mathrm{NHI}$ ) des Salmonidés. II. Données épidémiologiques en France. Pisciculture Français 91: 10-13

Hattenberger-Baudouy, A. M., Danton, M., Merle, G., Torchy, C., de Kinkelin, P. (1989). Serological evidence of infectious hematopoietic necrosis in rainbow trout from a French outbreak of the disease. J. aquat. Anim. Health 1: 126-134

Hsu, Y. L., Engelking, H. M., Leong, J. C. (1986). Occurrence of different types of infectious hematopoietic necrosis virus in fish. Appl. environ. Microbiol. 52: 1353-1361

Kelly, R. K., Nielsen, O. (1990). Serological properties of neutralizing antibodies induced by vaccination of rainbow trout with distinct strains of infectious pancreatic virus. J. aquat. Anim. Health 2: 56-60

LaPatra, S. E., Fryer, J. L., Wingfield, W. H., Hedrick, R. P. (1989). Infectious hematopoietic necrosis virus (IHNV) in coho salmon. J. aquat. Anim. Health 1: 277-280

Responsible Subject Editor: F. M. Hetrick, College Park, Maryland, USA
Luqi, N., Zhizhuang, Z. (1988). The epidemiological IHN and IPN of rainbow trout in northeast China. J. Fish. China 12: $327-333$

Mandel, B. (1985). Virus neutralization. In: Regenmortel, M. H. V., Neurath, A. R. (eds.) Immunochemistry of viruses. The basis for serodiagnosis and vaccines. Elsevier, Amsterdam, p. 53-70

McCain, B. B., Fryer, J. L., Pilcher, K. S. (1971). Antigenic relationships in a group of three viruses of salmonid fish by cross neutralization. Proc. Soc. exp. Biol. Med. 137: 1042-1046

Olesen, N. J., Jørgensen, P. E. V. (1986). Detection of neutralizing antibody to Egtved virus in rainbow trout (Salmo gairdneri) by plaque neutralization test with complement addition. J. appl. Ichthyol. 2(1): 33-41

Ristow, S. S., Arnzen, J. (1991). Monoclonal antibodies to the glycoprotein and nucleoprotein of infectious hematopoietic necrosis virus (IHNV) reveal differences among isolates of the virus by fluorescence, neutralization and electrophoresis. Dis. aquat. Org. 11: 105-115

Sano, T., Nishimura, T., Okamoto, N., Yamazaki, T., Hanada, H., Watanabe, Y. (1977). Studies of viral diseases of japanese fishes. VI. Infectious hematopoietic necrosis (IHN) of salmonids in the mainland of Japan. J. Tokyo Univ. Fish. 63: 81-85

Vestergård-Jørgensen, P. E. (1972). Freund's adjuvants: their influence on the specificity of viral antisera. Acta path. microbiol. scand. Sec. B 80: 931-933

Vestergård-Jørgensen, P. E., Olesen, N. J., Lorenzen, N., Winton, J. R., Ristow, S. S. (1991). Infectious hematopoietic necrosis (IHN) and viral hemorrhagic septicemia (VHS): detection of trout antibodies to the causative viruses by means of plaque neutralization, immunofluorescence, end enzyme-linked immunosorbent assay. J. aquat. Anim. Health 3: $100-108$

Winton, J. R. (1991). Recent advances in detection and control of infectious hematopoietic necrosis virus in aquaculture. A. Rev. Fish Dis. 1:83-93

Winton, J. R., Arakawa, C. K., Lannan, C. N., Fryer, J. L. (1988). Neutralizing monoclonal antibodies recognize antigenic variants among isolates of infectious hematopoietic necrosis virus. Dis. aquat. Org. 4: 199-204

Wolf, K. (1988). Infectious hematopoietic necrosis. In: Fish viruses and viral fish diseases. Cornell University Press, Ithaca, p. 83-114

Manuscript first received: September 3, 1992

Revised version accepted: January 8, 1993 